\title{
CURRENT DEVELOPMENTS
}

\author{
Giving Money to Children: The State's Constitutional Obliga- \\ tions to Provide Child Support Grants to Child Headed House- \\ HOLDS*
}

\section{INTRODUCTION}

One of the most tangible effects of the HIV epidemic is the growing number of orphans and the emergence in ever increasing amounts of households headed by children. These new family configurations pose a wide range of challenges to our society. Not least of these is the challenge to change laws that hamper these households from accessing desperately needed benefits. The state currently provides a child support grant (CSG) for children in need. This grant (R170 per month from 1 April 2004) is provided to the 'primary care giver' (PCG) of a child who is currently under the age of 11 years. ${ }^{1}$ Neither the Social Assistance Act, nor the regulations promulgated under it set any age limit for the PCG. Effectively, however, such a person must be 16 years old as this is the age when an identity document is first provided, ${ }^{2}$ and a PCG has to provide his or her identity document in applying for the grant. ${ }^{3}$ In practice, the various offices of the Department of Social Development, responsible for administering the CSG, are treating applicants differently and some are even turning away those who are under the age of $21 .^{4}$

This note argues that the exclusion of children living in child-headed households from the child support grant programme constitutes a violation of the Constitution. In particular, the rights to equality and social security, as well as children's socio-economic rights, are being

\footnotetext{
* An earlier version of this note was presented at the ACESS/Children's Institute Workshop on 'Children without Adult Caregivers and Access to Social Assistance' held on 20-21 August 2003 in Cape Town. For background to this issue see the paper prepared for the same workshop by $\mathrm{S}$ Rosa 'Access to Social Assistance for Children without Adult Primary Caregivers' (2003) (copy on file with authors). The authors would like to thank Solange Rosa, Cathi Albertyn and Tshepo Mosikatsana for their assistance in discussing certain aspects of this note.

1 Sections 2(d) and 4 of the Social Assistance Act 59 of 1992, read with the regulations to the Act (Government Notice 418 of GG 18771 (31 March 1998) as amended by Government Notice 813 of 25 June 1999, Government Notice 1233 of 23 November 2001, Government Notice 460 of 31 March 2003 and Government Notice 409 of 26 March 2004. In terms of the March 2003 amendments, the CSG has been extended to children under the age of fourteen, to be phased in over the period 200305 . The primary care-giver must past a means test, which is prescribed in reg 16.

2 Section 3 of the Identification Act 68 of 1997.

3 Reg 9 (1) to the Social Assistance Act.

4 L Altenroxel 'Hungry? Give them a Gutsfull of Red Tape' The Star (30 April 2003) 14-5.
} 
breached. ${ }^{5}$ Before looking at each of these in turn, the history of the CSG, the context of child headed households $(\mathrm{CHH})$ and the legal approach towards families will be discussed briefly.

\section{The Child Support Grant}

The CSG is one of the grants provided as part of the government's social assistance programme. ${ }^{6}$ It originated in the recommendations of the Report of the Lund Committee on Child and Family Support (the Lund Report). ${ }^{7}$ Its primary purpose is to provide a regular source of income to care-givers of children living in poverty to assist them to meet the basic needs of children in their care. ${ }^{8}$

One of the innovative features introduced by the Lund Report is the concept that the payment of the grant should not depend on biological ties and common law relationships where a duty of support towards a child exists. Rather, it should be based on a factual assessment of the person who is assuming primary responsibility for the daily care needs of the child. As expressed in the Report, the payment of the child support grant to the primary care-giver of the child 'resolves the problem of how to define the family in such a complex and multi-cultured society'. It says that 'children, however many in a household, of whatever status, are important and need to be protected' (emphasis added). ${ }^{9}$ The recommendation that the grant 'follow the child' also underscores a functional definition of the primary care-giver by recognising the reality that children living in poverty may have successive care-givers. ${ }^{10}$ This is particularly important in the context of HIV/AIDS where many children lose the benefit of the child support grant upon the death of their primary care giver instead of the grant being transferred to whoever, as a matter of fact, assumes primary responsibility for the care of that child. ${ }^{11}$ The Report also views the goal of family preservation as being achieved most

5 As in the case of Khosa v Minister of Social Development (CCT 12/03, unreported) and Mahlaule v Minister of Social Development (CCT 13/03, unreported) this is a situation where we are concerned with 'intersecting rights which reinforce one another at the point of intersection' (para 41). In addition, the rights to life and dignity are implicated. In these cases, the Constitutional Court held that the exclusion of permanent residents from eligibility to various social grants in the Social Assistance Act (as amended by the Welfare Laws Amendment Act 107 of 1997) was inconsistent with both s 27 (the right of access to social security) and $\mathrm{s} 9$ (the right to equality) in the Constitution.

6 The CSG replaced the State Maintenance Grant and was included in the Social Assistance Act by the Welfare Laws Amendment Act 105 of 1997.

7 Report of the Lund Committee on Child and Family Support, August 1996.

8 Ibid 'Executive Summary' 4-5.

9 Ibid 91.

10 See further Lund Report (note 7 above) 18.

11 S Giese, H Meintjes, R Croke \& R Chamberlain Health and Social Services to Address the Needs of Orphans and Other Vulnerable Children in the context of HIV/AIDS Research Report and Recommendations (2003) Children's Institute (UCT) and National Department of Health South Africa (hereafter 'Children's Institute/Department of Health Report') 106. 
effectively by focusing on the child, rather than on the nuclear family, in the face of changing family forms.

This functional concept of the person entitled to claim the CSG was adopted in the Social Assistance Act $^{12}$ with certain safeguards. These include that the primary care-giver has the implied or express consent of a parent, guardian or custodian and that the CSG can be claimed on behalf of a maximum of six non-biological children or children who have not been legally adopted. ${ }^{13}$ The definition of 'implied consent' in the regulations includes the absence of any objection from the parent, guardian or custodian of a child remaining in the custody of the primary care-giver 'on account of such parent, guardian or custodian being deceased'. ${ }^{14}$ This is significant in the case of children without adult caregivers in the context of HIV/AIDS.

\section{The Position of Child Headed Households}

Although the Lund Report did not directly address the question of the payment of grants to children on behalf of other children (eg siblings), it acknowledged the profound effects of the AIDS epidemic on family life and household composition, including a change in the productive role of younger children, with many of them having to leave school to care for younger siblings. ${ }^{15}$ As many subsequent studies have documented, young children who have lost a parent or other primary adult care-giver are in a particularly vulnerable situation. They usually lose access to the practical, financial and emotional care as well as the protection provided by their parents or other primary care-giver. They are also vulnerable to discrimination, exclusion from basic services, and have difficulty in maintaining school attendance. ${ }^{16}$

12 Section 1 of the Social Assistance Act defines the 'primary care-giver' as 'a person, whether or not related to the child, who takes primary responsibility for meeting the daily care needs of the child, but excludes (a) a person who receives remuneration, or an institution which receives an award, for taking care of the child; or (b) a person who does not have an implied or express consent of a parent, guardian or custodian of the child'. The factual nature of the assessment as to who is the primary care-giver is also supported by s 4 which requires the Director General to be satisfied that the claimant is the primary care-giver of the child. Regulation 20 of the regulations to the Act imposes duties on recipients of the CSG to ensure that the child has accommodation, is properly fed and clothed and receives immunisations and other health services where these are available without charge.

13 Reg 3 (note 1 above).

14 Reg 1 (note 1 above).

15 Lund Report (note 7 above) 19.

16 See J Sloth-Nielsen 'Too Little? Too Late? The Implications of Grootboom for State Responses to Child-headed Households' (2003) 7 Law Democracy \& Development 113. See also Nelson Mandela Children's Fund A Study into the Situation and Special Needs of Children in Childheaded Households (2001) available at < http://www.mandela-children.com/english/worddoc/ Report.doc > ; Thandanani Children's Foundation The Nature and Extent of Problems Facing Child-headed Households with the Thandanani Programme (March 2003). The Children's Institute/Department of Health Report (note 10 above) 57 cautions that it is important not to lose sight of the fact that children living with terminally ill care-givers are in a similarly vulnerable position. 
In their seminal study on orphans and other vulnerable children in the context of HIV/AIDS, the Children's Institute caution that 'idealising particular care arrangements, or rejecting others outright, inappropriately stereotypes the nature of household forms'. ${ }^{17}$ Such 'idealising' fails to take into account the complexity of children's experiences within different contexts. Thus, living with relatives in the context of orphanhood is not necessarily a better option for children than living without adults: 'If adequately supported (a crucial caveat), children living alone can find themselves safer than if living with adults'. ${ }^{18}$ They accordingly advocate that, 'although widely considered to be an anomalous household form, children living without adults should be viewed within their broader contexts and, where appropriate, supported in their current living arrangements'. ${ }^{19}$ This supports a contextual evaluation of which living arrangements best promote the well-being of children when faced with the loss of their parents or other primary adult care-givers. However, 'the crucial caveat' of adequate support for children living alone should be noted. ${ }^{20}$

The South African Law Reform Commission (SALRC) has also proposed the recognition of child-headed households as a placement option for orphaned children in need of care subject to a link to suitable adult and state support. ${ }^{21}$ The SALRC has furthermore recommended that the CSG must be administered in such a way that it reaches childheaded households. In the case where 'a child may be too young and immature to be entrusted with total responsibility for his or her siblings', the SALRC recommended putting in place a system of 'household mentors' who would be able to access grants and other social benefits on behalf of the $\mathrm{CHH}^{22}$

17 Children's Institute/Department of Health Report (note 11 above) xiv.

18 Ibid.

19 Ibid.

20 In its General Comment 3 HIV/AIDS and the Rights of the Child (2003) the UN Committee on the Rights of the Child says that state parties (to the Convention on the Rights of the Child) 'are encouraged to provide support, financial and otherwise, when necessary, to child-headed households'. This is in recognition of the factual reality that the preferable option of enabling siblings to remain together in the care of relatives or family members 'may not be available due to the impact HIV/AIDS has on the extended family'. UN doc CRC/GC/2003/1 para 31.

21 SALRC Project 110 Review of the Child Care Act Report (December 2002) 169. This is further supported by the SALRC's broad, inclusive definition of the family that 'should be relationship focused and should entrench a non-traditional approach to family relations' (ibid 58-9). See also the broad definition of 'family member' in s 1 of the Draft Children's Bill B2003 (12 August 2003).

22 SALRC Project 110 Review of the Child Care Act Discussion Paper 103 vol 3 (December 2001) 562; SALRC Report (note 21 above) 169 70. The Draft Children's Bill provides for a designated organ of state or non-governmental organisation to collect and administer social grants on behalf of the child-headed household. It furthermore provides that the "child heading the household may take all day-to-day decisions relating to the household and the children in the household as if that child was an adult primary care-giver'. Draft Children's Bill s 136 (5). The notion that the CSG can be paid to a third party to administer on behalf of the 


\section{The Changing Nature of Family Forms}

An important argument for the recognition of minors as PCGs is that while they may lack capacity in law, in practice they are performing 'adult' functions. The nature of family life is shaped, inter alia, by the historical and socio-economic conditions in any society. In South Africa, the history of colonialism and the creation of a migrant labour system have had devastating effects on family life. ${ }^{23}$ Millions of children live apart from their parents in many types of family arrangements. While grandparents, aunts and other adult relatives are often the PCGs of children whose mothers are elsewhere, many children are left in rural areas without adult care. The AIDS epidemic, as discussed above, has only worsened an already difficult situation. Older children often perform all or some of the functions of a PCG. They buy food, prepare it, dress and feed younger children, etc. There is also a gender dimension to the shaping of South African family life. Many thousands of fathers abandon their children and take neither physical nor financial responsibility for them. ${ }^{24}$ Thus, even where a child has a father who is alive, when she or he loses a mother, the child is often effectively parentless.

In recent years, our courts and the legislature have begun to recognise new types of family and family arrangements that do not fit within the traditional definitions. Thus, gay and lesbian relationships have now been recognised and protected in many cases. ${ }^{25}$ It has been acknowledged that unmarried fathers have been unfairly treated. ${ }^{26}$ Customary and Muslim marriages and domestic partnerships have also been given greater rights. ${ }^{27}$ Justice O'Regan has said the following:

child is already contemplated in the Social Assistance Act, s 8 of which empowers the Director General if he is of the opinion that a beneficiary has misspent his or her grant or if he deems it expedient for any other reason to 'appoint a person to receive the grant on behalf of the beneficiary and to apply it, subject to the prescribed conditions and such further conditions as the Director General may determine for the benefit of that beneficiary' (emphasis added).

23 See S Burman 'Capitalising on African Strengths: Women, Welfare and the Law' (1991) 7 SAJHR 2, 215; M Ramphele A Bed Called Home (1993) ch 6 for a discussion of the impact of migrancy on families.

24 See S Wamhoff \& S Burman 'Parental Maintenance for Children: How the Private Maintenance System might be Improved' (2002) 28 Social Dynamics 146, 147.

25 Langemaat $v$ Minister of Safety and Security 1998 (3) SA 312 (T); National Coalition for Gay and Lesbian Equality v Minister of Home Affairs 2000 (2) SA 1 (CC); Satchwell v President of the RSA 2002 (6) SA 1 (CC); Du Toit v Minister for Welfare and Population Development 2003 (2) SA 198 (CC); Jv Director-General, Department of Home Affairs 2003 (5) SA 621 (CC).

26 Fraser v Children's Court, Pretoria North 1997 (2) SA 261 (CC).

27 Recognition of Customary Marriages Act 120 of 1998; Amod v Multilateral Motor Vehicle Accidents Fund (Commission for Gender Equality Intervening) 1999 (4) SA 1319 (SCA) and Daniels v Campbell (CCT 40/03, unreported) extending benefits to Muslim marriages. See also SALRC Project 118 Domestic Partnerships Discussion Paper 104 (September 2003) 53-5. The recent case of Robinson $v$ Volks (CPD 7178/03, unreported) improves the position of domestic partners in our law. 
families come in many shapes and sizes. The definition of family also changes as social practices and traditions change. In recognising the importance of the family, we must take care not to entrench particular forms of family at the expense of other forms. ${ }^{28}$

The developments in the legal meaning of family are an international trend that finds support in the theoretical writings of some of the leading family law thinkers. ${ }^{29}$ Martha Minow's 'functional approach' is particularly useful for determining whether parties to a particular family relationship should be given protection by the law. ${ }^{30}$ This approach goes beyond traditional categories of biology and marriage to look at how people function as a family. Minow says that certain people may not fit a 'formal' legal definition of a family. 'Instead, what is important is whether the group of people function as a family: do they share affection and resources, think of one another as family members, and present themselves as such to neighbours and others?. ${ }^{31}$ This approach is particularly useful in the South African context and is necessary if we are to give effect to the values and rights in our Constitution.

\section{The Right to Social Assistance}

A distinction is usually drawn between social security (contributory and usually linked to formal employment) and social assistance (needs-based, non-contributory and paid directly from public funds). The western model of the residual role of social assistance (as a safety net when social insurance schemes or private savings fail) simply does not fit in developing countries. This is due to systemic poverty and inequality combined with high levels of structural unemployment. ${ }^{32}$ In the South African context, social assistance plays a critical role in poverty alleviation. ${ }^{33}$ The Minister of Finance has acknowledged that social

28 Dawood v Minister of Home Affairs 2000 (3) SA 936 (CC) para 31.

29 See J Sinclair The Law of Marriage (1996) 5-15 for a discussion of this trend and the leading writers commenting on it.

30 M Minow 'Redefining Families: Who's In and Who's Out?' (1991) 62 Colorado LR 2, 269. Also as discussed and applied in B Goldblatt 'Amod v Multilateral Motor Vehicle Accidents Fund (Commission for Gender Equality Intervening)' (2000) 16 SAJHR 138, 142-43; B Goldblatt 'Regulating Domestic Partnerships A Necessary Step In The Development Of South African Family Law' (2003) 120 SALJ 610

31 Ibid 270

32 On the context of poverty and inequality in South Africa, see S Liebenberg 'The Right to Social Assistance: The Implications of Grootboom for Policy Reform in South Africa' (2001) 17 SAJHR 232, 23437.

33 See for example, A Case \& A Deaton Large Cash Transfers to the Elderly in South Africa (1996) Princeton Research Program in Development Studies Discussion Paper 176. See also Lund Report (note 7 above) on the benefits to poor households of cash transfers, 5-10. In the Khosa and Mahlaule decision (note 5 above) para 52, the Court observed that the right of access to social security, including social assistance, for those unable to support themselves and their dependants 'is entrenched because as a society we value human beings and want to ensure that people are afforded their basic needs'. 
assistance is the largest single redistributive programme of government. ${ }^{34}$ In many poor households, grants often represent the only form of income and support.

The right to social security as a human right widely recognised in international law is part of the body of rights collectively concerned with people's material well-being. ${ }^{35}$ It is also a right recognised in s 27(1)(c) of the Constitution. That section, read with s 27(2), provides:

Everyone has the right to have access to ....

(c) social security, including, if they are unable to support themselves and their dependants appropriate social assistance

(2) The state must take reasonable legislative and other measures, within its available resources, to achieve the progressive realisation of each of these rights.

There have been four Constitutional Court cases dealing with the interpretation of the socio-economic rights protected in ss 26, 27 and $28 .{ }^{36}$ The foundations of the constitutional jurisprudence on these rights were laid in the Grootboom decision.

\section{(a) Who is the bearer of the right to social assistance?}

There are three main questions that arise in relation to the bearer of the right to social assistance. This right is conferred on 'everyone', thus clearly extending to both adults and children. ${ }^{37}$ While it would normally

34 Minister of Finance, Trevor Manual, Budget Speech 2001/2002 available at <http:// www.polity.org. za/govdocs/budgets/index.html > . According to the evidence of the Chief Director of Social Services in Khosa and Mahlaule (note 5 above), 'the development of a system of social grants has been a key pillar of the government's strategy to fight poverty and promote human development' (ibid para 60).

35 See for example, the Universal Declaration of Human Rights arts 22, 25; the International Covenant on Economic, Social and Cultural Rights arts 9, 10(2)-(3), 11; the Convention on the Elimination of all forms of Discrimination against Women arts 11(1)(e), 11(2)(b), 14(2); the Convention on the Rights of the Child arts 26, 27(1) (3); the Convention on the Elimination of All Forms of Racial Discrimination art 5 (e) (iv). See also S Liebenberg 'Social Security as a Human Right' in International Human Rights Internship Program and Asian Forum for Human Rights and Development Circle of Right - Economic, Social and Cultural Rights Activism: A Training Resource (2000) 200.

36 Soobramoney v Minister of Health, Kwa-Zulu-Natal 1998 (1) SA 765 (CC); Government of the Republic of South Africa v Grootboom 2001 (1) SA 46 (CC) ('Grootboom'); Minister of Health v Treatment Action Campaign 2002 (5) SA 721 (CC) ('TAC'); Khosa and Mahlaule v Minister of Social Development (note 5 above).

37 The Court in Grootboom held that '[o]ne of the ways in which the State would meet its section 27 obligations would be through a social welfare programme providing maintenance grants and other material assistance to families in need in defined circumstances' (para 78). In Khosa and Mahlaule (note 5 above), the Constitutional Court dealt with the question whether 'everyone' in subsec (1) of ss 26 and 27 included permanent residents (see paras 46 7). The Court said: 'The constitutional reference to 'everyone' implies that all in need must have access to the social welfare scheme that the state has put in place. Where some who are in need are excluded, everyone does not have access to the scheme. The word 'everyone' is a term of general import and unrestricted meaning. It means what it conveys. Once the state puts in place a social welfare system, everyone has a right to have access to that system' (ibid para $111)$. 
be an adult (the PCG) in the case of the CSG who claims the grant on behalf of the child, the absence of an adult PCG does not mean that the child's entitlement to the grant lapses. A second question concerns the group who is regarded as being 'unable' to support themselves and their dependants. The underlying purpose of the right to social assistance is to ensure that persons living in poverty enjoy access to a minimum income, sufficient to meet basic subsistence needs so that they do not have to live below minimum acceptable standards. ${ }^{38}$ It follows that the right should belong to all those who are unable (whether through disability, age or, in the case of adults, the inability to find employment) to gain access to the income necessary to secure their basic subsistence needs. Finally, with regard to those unable to support themselves and their dependants, the concept of dependency should be a factual one, and not confined to situations where a duty of support is formally recognised by law. ${ }^{39}$

\section{(b) The state's obligations in relation to this right}

The Court will not prescribe any particular social programme to government, but will enquire into whether the programme is reasonable. ${ }^{40}$ A number of criteria were established in order for a government programme to be considered reasonable. These include requirements that the state must -

- establish a co-ordinated and comprehensive programme that is 'capable of facilitating the realisation of the right'; 4 ,

- ensure that policies and programmes are reasonable both in their conception and their implementation ${ }^{42}$; and

- ensure that the programme does not exclude those in desperate need and living in intolerable conditions. ${ }^{43}$

In respect of the latter requirement, the Court wrote the following in Grootboom:

A programme that excludes a significant segment of society cannot be said to be reasonable. ... A society must seek to ensure that the basic necessities of life are provided to all if it is to be a society based on human dignity, equality and freedom. To be reasonable, measures cannot leave out of account the degree and extent of the denial of the right they endeavour to realise. Those whose needs are most urgent and whose ability to enjoy all rights therefore is most in peril, must not be ignored by the measures aimed at achieving the realisation of the right (emphasis added). ${ }^{44}$

\footnotetext{
38 This is a fundamental objective set out in Department of Social Development White Paper for Social Welfare (February 1997) ch 7 para 27. See also note 33 above.

39 This is argued more fully in Liebenberg (note 32 above) 240 .

40 Grootboom (note 36 above) para 41.

41 Ibid paras 401

42 Ibid para 42.

43 Ibid para 43 4; 68.

44 Ibid para 44.
} 
In $T A C$, the Court again emphasised the point that a programme aimed at the realisation of socio-economic rights will not pass the constitutional test of reasonableness if it excludes groups in especially vulnerable circumstances. $^{45}$

We have argued above that children living without adult care-givers in poor communities (whose resources are also depleted due to the ravages of the AIDS epidemic) are for the most part in an extremely vulnerable situation. This vulnerability is due to the absence of adult protection and care and to the circumstances of extreme poverty in which they live. Their survival and development needs are, by any account, 'most urgent' and their enjoyment of a range of other rights is in peril, for example, the rights to nutrition, education and health care. Their inability to access the CSG deprives them of a critical state programme that was specifically designed to meet the basic needs of children living in poverty. There are no other state programmes designed to meet these needs that are based on a system of legislative entitlement, and are as extensive in their reach and the amount of resources going directly to the beneficiaries.

\section{CHILDREN's SOCIO-ECONOMIC Rights}

Another relevant constitutional right is the right of every child 'to basic nutrition, shelter, basic health care services and social services' in $\mathrm{s}$ $28(1)(c) .{ }^{46}$ This provision is not subject to the qualifications that one finds in ss 26(2) and 27(2). Although the right to social assistance is not directly included in this provision, the child support grant is clearly a major programme through which these basic needs of children are met. ${ }^{47}$

On the face of it this right imposes a direct obligation on the state to ensure that these basic needs of children are met. In Grootboom, the Court held that s 28(1)(b) (the right to family care or parental care, or to appropriate alternative care when removed from the family environment) and s 28(1)(c) must be read together. Thus the primary obligation to meet these entitlements of children rests on their parents and families. It is only when children lack family care (eg if they are removed from their families or abandoned) that the state incurs an obligation to provide shelter to children.

In $T A C$, the Court held that the state's duty to provide health care services also arises 'when the implementation of the right to parental or

45 TAC (note 36 above) paras 789.

46 Section 28(3) defines a child as a person under the age of 18 years.

47 On the meaning of the term, 'social services' in this context, see the discussion by J SlothNielsen 'The Child's Right to Social Services, the Right to Social Security, and the Primary Prevention of Child Abuse: Some Conclusions in the Aftermath of Grootboom' (2001) 17 SAJHR 210, 225 26. In Khosa and Mahlauli (note 5 above) para 78, the Court held that the exclusion of children from the child support grant programme on the basis of their parents' nationality also 'trenches upon their rights under section 28(1)(c) of the Constitution'. 
family care is lacking, ${ }^{48}$ This includes situations where parents are too poor to access private medical treatment and are thus dependent on the state to make health care services available to them. ${ }^{49}$ Despite this interpretation, the Court proceeded to apply the reasonableness test developed in respect of the right of access to health care services in $\mathrm{s}$ 27(1)(a) read with s 27(2). ${ }^{50}$

It is arguable, based on the Grootboom reasoning, that the state incurs a direct obligation to provide for the basic material needs of children living without adult care-givers. This duty arises because children are deprived of their primary sources of support and care. The CSG is a critical mechanism for meeting the state's obligations towards poor children. Where children lose their PCG, this should not signify a deprivation of the resources necessary for their continued survival and development. ${ }^{51}$ On the contrary, it signifies a heightened need for mechanisms to be put in place to ensure that these children continue to enjoy, or begin to enjoy, access to the CSG. Even if the reasonableness test were applied, the blanket exclusion of children living without adult support from the CSG grant would not pass the test laid down in Grootboom.

\section{The Right to EQuality}

Equality is both an underlying value and a fundamental right in the Constitution. The right to equality in s 9(1) states that 'everyone is equal before the law and has the right to equal protection and benefit of the law'. Section 9(3) prohibits unfair discrimination ${ }^{52}$ by the state 'directly or indirectly' on the basis of a list of grounds (while also allowing for the possibility of further unlisted grounds). ${ }^{53}$ While the Constitutional Court has not considered all of these grounds, the jurisprudence on equality is well developed.

The refusal by the Department of Social Development to provide a CSG to a minor PCG could violate s 9(1). Here it must be shown that the different treatment of adults and children is not based on a 'rational connection to a legitimate government purpose'.${ }^{54}$ Even if the state could

$48 T A C$ (note 36 above) para 79.

49 Ibid.

50 Ibid para 122.

51 See the Children's Institute/Department of Health Report (note 11 above) 106 para 5.3.2.4 on the severe consequences for children of an interruption of the CSG when their PCG dies.

52 The test for unfair discrimination is set out in Harksen $v$ Lane 1998 (1) SA 300 (CC) para 38.

53 For example, the Constitutional Court found there to be unfair discrimination on the basis of the unlisted ground of citizenship in Larbi-Odam v MEC for Education (North-West) 1998 (1) SA 745 (CC). See also Khosa and Mahlauli (note 5 above) where the Court held that the exclusion of permanent residents from the social grants system, in addition to violating s 27 , constituted unfair discrimination under s 9 (paras 68 78) which is not justifiable under s 36 (paras 79 80).

54 According to the test set out in Prinsloo v Van der Linde 1997 (3) SA 1012 (CC) and Harksen v Lane (note 52 above). 
pass this hurdle, s 9(3) would present a problem. There are a number of listed grounds of unfair discrimination that seem applicable to the issue of minor PCGs claiming grants. ${ }^{55}$ The Constitution, in s 9(5), creates a presumption of unfairness if a claim of unfair discrimination is made on the basis of a listed ground. Thus, the state would have to establish that the discrimination was not unfair (or that the discrimination was not in fact based on the listed ground alleged).

The most likely ground of unfair discrimination is 'age'. The fact that a PCG is a minor does not mean that she or he is not fulfilling the functions of a PCG. The Act sets no age limit on PCGs. It is unfair discrimination to give a grant to a 21 year old but not to a 20 year old or 16 year old or even a 14 year old who is performing the identical functions of a PCG. The contextual evidence discussed above, regarding the actual responsibilities that children fulfil on a daily basis because of migrancy, poverty and orphanhood, lends credence to this argument. In addition, the growing recognition by the law that families and their members must be judged by the functions they perform, rather than according to some inflexible standard, also supports this argument.

The listed ground of 'social origin' might also be used, together with the ground of 'age', in claiming unfair discrimination against minor PCGs. Poverty, HIV/AIDS and migrancy create the conditions within which children look after children and take financial and other responsibilities for younger children. The failure to recognise this and assist such children is to discriminate unfairly against them because they come from poor backgrounds. Possibly, the ground of 'birth' might also be used on the basis of the argument that there is unfair discrimination against AIDS orphans.

All of the above grounds intersect ${ }^{56}$ with 'gender' and 'sex' since it is primarily women who are the PCGs. ${ }^{57}$

A challenge to the practice of refusing the CSG to PCGs who are children might also be challenged under South Africa's equality legislation, the Promotion of Equality and Prevention of Unfair Discrimination Act 4 of 2000. This Act arose from the mandate in s 9(4) of the Constitution to create national anti-discrimination legislation. The Act gives content to the equality right and provides detailed mechanisms for people to approach the courts when they claim they have suffered

55 It should be noted that there is another category of minors, teenage mothers, who are sometimes refused grants. It is possible that such refusal is unfair discrimination on the grounds of sex, pregnancy or gender. For a discussion of the negative perceptions regarding young mothers who claim the CSG, see B Goldblatt 'Teen Pregnancy and Abuse of the Child Support Grant. Addressing the Myths and Stereotypes' (2003) 56 Agenda 79.

56 See NCGLE v Home Affairs (note 25 above) para 38 regarding overlapping and intersecting grounds of unfair discrimination.

57 CASE Phasing in the Child Support Grant-A Social Impact Study (2000) 45. This research was done for the Department of Welfare. 
discrimination. ${ }^{58}$ The list of prohibited grounds of discrimination in the Act is the same as those found in s 9(3) of the Constitution. The Act does, however, contain five additional grounds that Parliament may include in the list of prohibited grounds after consideration by the Equality Review Committee and the Minister of Justice. ${ }^{59}$ Of these, the grounds of 'socioeconomic status' and 'family status' might be possible grounds of unfair discrimination with regard to minor claimants of the CSG. 'Socioeconomic status' could be used in a similar manner to the ground of 'social origin'. 'Family status' discrimination arises because of the type of family that a person comes from, for example, children whose parents have died of AIDS, or who are looked after by children, or who are orphans and are treated unfairly as a result of this status. It may be possible to show that child applicants are being turned away because of the types of families that they come from.

In arguing that the discrimination is not unfair, the state might raise issues of law and principle regarding the legal age of majority and the inability of children to take responsibility for controlling and using money on behalf of other children. The state might also raise the problem of the lack of a cut-off age under which a CSG cannot be given, ie that the state might be expected to give the grant to a very young child. The response to this would be that in terms of the legislation the grant can only be given to someone who is the de facto PCG of a child. ${ }^{60}$ If the minor care giver can look after a child and apply for a grant then she or he should be entitled to a CSG.

\section{LIMITATIONS}

If the above arguments failed, the state would still have an opportunity to argue that it is 'reasonable and justifiable in an open and democratic society based on human dignity, equality and freedom' to limit the rights in question. ${ }^{61}$ Here, the state is likely to raise practical arguments about the lack of administrative and/or financial capacity of the Department of Social Development to assess whether a child is capable of using the CSG properly or to monitor his or her use of the grant. However, the state bears the burden of showing a sufficiently weighty purpose for limiting the rights, and must comply with the elements of the proportionality test. This includes establishing that less restrictive means have been considered for achieving the state's purposes other than a rigid, blanket exclusion of

58 See C Albertyn, B Goldblatt \& C Roederer Introduction to the Promotion of Equality and Prevention of Unfair Discrimination Act 4 of 2000 (2001).

59 Section 34. The Equality Review Committee is a body set up in terms of s 32 of the Act. At the time of writing, the Minister has not yet decided whether any of these grounds should be included as prohibited grounds.

60 Section 4 of the Social Assistance Act.

61 In terms of s 36 of the Constitution. The limitations arguments might apply to all the violated rights discussed above ie: equality, social security and children's rights. 
children without adult care givers from the CSG programme. In the circumstances it is doubtful whether the state would succeed in establishing a limitation of the rights concerned. ${ }^{62}$

\section{CONCLUSION}

The government is both mindful of its obligations under the Constitution and aware that the South African reality of child headed households must be accommodated in providing services and support. The Minister of Social Development has 'expressed outrage at municipalities that charge households headed by children the usual rates and taxes'. ${ }^{63} \mathrm{He}$ said 'minors are obviously unemployed and cannot even afford to feed themselves and their siblings ... they cannot be expected to pay rates and should not be subjected to water and electricity cuts' ${ }^{64}$ In addition, a new Social Assistance Bill ${ }^{65}$ has changed the definition of PCG (previously not subject to an age limit) to apply to 'a person older than 16 years'. ${ }^{66}$ While this amendment reflects an appreciation that children may look after other children, the exclusion of children under the age of 17 is problematic. As we have argued, there are many children who function as PCGs of younger children who would be excluded by this age limit.

A rigid and inflexible policy that prevents all children without adult care givers from accessing the CSG is susceptible to constitutional challenge. A more flexible, nuanced approach is required which takes into account the actual and varied circumstances in which children without adult care givers live. In certain circumstances, it may be appropriate for children to access the grant directly on behalf of both themselves and younger siblings in their care, and in other cases a system of paying the grant to a 'household mentor' as proposed by the SALRC would be more appropriate. ${ }^{67}$ At the very least, it is incumbent on the state to make a serious and concerted effort to ensure that children without adult care-givers are not deprived of the financial support conferred by the CSG. It is important that the Act and regulations be amended to include proactive measures for ensuring that this group of children gains effective access to the child support grant. This includes measures for identifying children without adult care-givers, assessing their needs, and then putting in place suitable mechanisms for ensuring

62 See, for example, the proposals of the SALRC (note 22 above) for including children living in child-headed households within the child support grant programme.

63 Quoted in Business Day (1 August 2003) 4.

64 Ibid.

65 B57 of 2003, as introduced in the National Assembly as a s 76 Bill, explanatory summary of Bill published by GN 2173 in GG 25340 of 8 August 2003.

66 Ibid, s 1 (definitions).

67 See note 22 above and accompanying text. 
that they receive the benefit of the child support grant. Clearly this will require additional resources and capacity. However, this investment is required in order to honour our constitutional commitments to vulnerable children.

Beth Goldblatt

Senior Researcher

Centre for Applied Legal Studies

University of the Witwatersrand

SANDRA LIEBENBERG

Harry Oppenheimer Chair in Human Rights

Faculty of Law

University of Stellenbosch 